\title{
Uraemic stomatitis
}

\author{
Hiroyuki Yano, ${ }^{1}$ Mitsuyo Kinjo (D) ${ }^{2}$
}

${ }^{1}$ Medicine, Okinawa Chubu Hospital, Uruma, Japan ${ }^{2}$ Okinawa Chubu Hospital, Uruma, Japan

\section{Correspondence to} Dr Mitsuyo Kinjo: kinjomitsuyo@gmail.com

Accepted 18 September 2019

\section{DESCRIPTION}

A 37-year-old man presented with generalised fatigue, dysgeusia and anorexia for 2 months. His medical and family history was non-contributory. He worked as a plumber and smoked five cigarettes per day for 17 years.

On arrival, he was alert and oriented. The body temperature was $36.3^{\circ} \mathrm{C}$, with blood pressure of $110 / 70 \mathrm{~mm} \mathrm{Hg}$, heart rate of 92 beats/min, respiration of 20 breaths/min and oxygen saturation of $100 \%$ on ambient air. He had an ammonia odour to the breath. Both lungs were clear on auscultation. Heart sounds were normal, without gallops or murmurs. He had no oedema. White plaque on the rim of tongue was notable (figure 1).

Laboratory studies showed a serum sodium of $141 \mathrm{mmol} / \mathrm{L}$, potassium of $5.0 \mathrm{mmol} / \mathrm{L}$, chloride of $105 \mathrm{mmol} / \mathrm{L}$, calcium of $4.4 \mathrm{mg} / \mathrm{dL}$ and phosphate of $18.0 \mathrm{mg} / \mathrm{dL}$. His blood urea nitrogen (BUN) level and serum creatinine (Cr) were 223.0 and $28.6 \mathrm{mg} / \mathrm{dL}$, respectively. Liver function tests were unremarkable. His albumin level was $4.1 \mathrm{mg} / \mathrm{dL}$. The complete blood counts showed a white blood cell count of $7000 / \mu \mathrm{L}$. His haemoglobin level was $68 \mathrm{~g} / \mathrm{L}$, haematocrit was $19.8 \%$, and mean corpuscular volume (MCV) was $87 \mathrm{fL}$, with a platelet count of $172000 / \mu \mathrm{L}$. Urinalysis showed proteinuria $(1.82 \mathrm{~g} / \mathrm{g} \mathrm{Cr})$ without red blood cells or casts. CT showed bilateral atrophic kidneys, indicating end-stage kidney failure of unknown aetiology. Haemodialysis was started along with alfacalcidol, lanthanum carbonate and darbepoetin alfa. His appetite and taste returned to normal, and the white patches on his tongue disappeared 1 week after renal replacement therapy (figure 2). He underwent a surgery for arteriovenous fistula formation, and haemodialysis was continued three times a week.

Uraemic stomatitis occurs in advanced renal failure with an elevated BUN level higher than $150 \mathrm{mg} / \mathrm{dL}$ and is a rare manifestation of uraemia. It resolves with earlier institution of renal replacement therapy. ${ }^{1}$ The chemical irritation of the oral mucosa

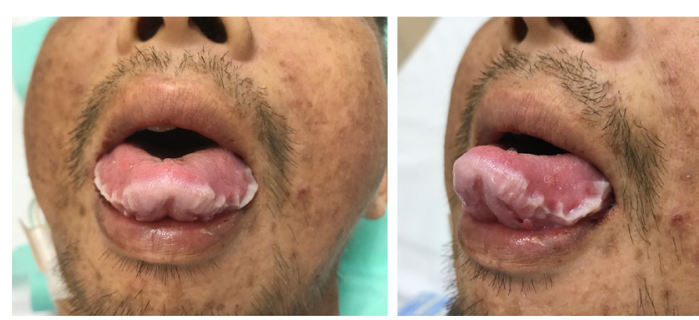

Figure 1 White plaque on the rim of the tongue was notable.

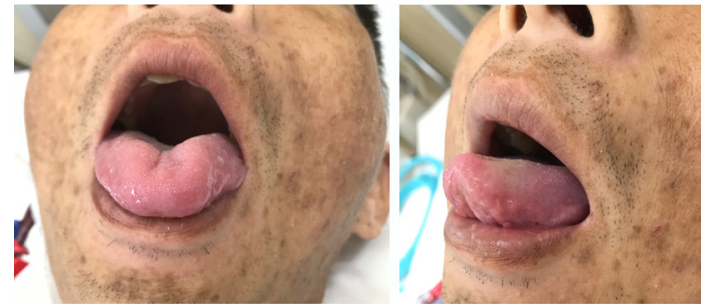

Figure 2 After several sessions of haemodialysis, the white patches on his tongue disappeared.

\section{Learning points}

Uraemic stomatitis is a rare complication of advanced renal failure.

- Anorexia and dysgeusia due to pain and discomfort of the tongue are the typical presentations.

- Uraemic stomatitis promptly improves after treatment of underlying uraemia.

with ammonia compound, which is made from nitrogen hydrolysed by urease in saliva, is presumed to cause uraemic stomatitis. Pain and discomfort of the tongue leading to anorexia and dysgeusia are the typical presentations. The four subtypes of stomatitis are erythemopultaceous, ulcerative, haemorrhagic and hyperkeratotic. Histology is characterised by a hyperplastic epithelium and unusual hyperparakeratinisation. The differential diagnosis includes vitamin deficiencies, lichen planus, oral hairy leukoplakia and chronic hyperplastic candidiasis. Uraemic stomatitis promptly improves after treatment of underlying uraemia. ${ }^{2}$

Acknowledgements The authors would like to acknowledge Dr Rita McGill for the language support.

Contributors HY and MK both contributed to writing the manuscript and editing the image.

Funding The authors have not declared a specific grant for this research from any funding agency in the public, commercial or not-for-profit sectors.

Competing interests None declared.

Patient consent for publication Obtained.

Provenance and peer review Not commissioned; externally peer reviewed.

ORCID iD

Mitsuyo Kinjo http://orcid.org/0000-0002-8342-230X

\section{REFERENCES}

1 Liao C-Y, Wu C-C, Chu P-L. Uremic stomatitis. QJM 2017;110:247-8.

2 Leão JC, Gueiros LAM, Segundo AVL, et al. Uremic stomatitis in chronic renal failure. Clinics 2005;60:259-62. 
Copyright 2019 BMJ Publishing Group. All rights reserved. For permission to reuse any of this content visit https://www.bmj.com/company/products-services/rights-and-licensing/permissions/

BMJ Case Report Fellows may re-use this article for personal use and teaching without any further permission.

Become a Fellow of BMJ Case Reports today and you can:

- Submit as many cases as you like

- Enjoy fast sympathetic peer review and rapid publication of accepted articles

Access all the published articles

Re-use any of the published material for personal use and teaching without further permission

Customer Service

If you have any further queries about your subscription, please contact our customer services team on +44 (0) 2071111105 or via email at support@bmj.com.

Visit casereports.bmj.com for more articles like this and to become a Fellow 